\title{
EFFECT OF MAGNETIC FIELD ON THE PHYSICAL AND CHEMICAL PROPERTIES OF FLOWING LUBRICATING COOLING LIQUIDS USED IN THE MANUFACTURING PROCESS
}

\author{
ERKIN ODILOV ${ }^{1}$, UMIDJON MARDONOV ${ }^{2 *}$, KHUSNIDDIN ABDIRAKHMONOV ${ }^{2}$, \\ ABDUGANi ESHKULOV ${ }^{1}$ AND BEHZOD RAKHMATOV ${ }^{3}$ \\ ${ }^{1}$ Faculty of Mechanic, \\ ${ }^{2}$ Faculty of Machine Construction, \\ Tashkent State Technical University, Tashkent, Uzbekistan \\ ${ }^{3}$ Faculty of Chemical Technology of Inorganic Substances, \\ Tashkent Institute of Chemical Technologies, Tashkent, Uzbekistan \\ "Corresponding author: fff8uma@mail.ru
}

(Received: $5^{\text {th }}$ January 2021; Accepted: $5^{\text {th }}$ March 2021; Published on-line: $4^{\text {th }}$ July 2021)

\begin{abstract}
In this paper, the effect of magnetic field on lubricating cooling liquids, which are used in the cutting process in manufacturing, was studied. We chose three different lubricating cooling liquids that are commonly used in local manufacturing factories to conduct the experiment. Three main properties of these lubricoolants, boiling point, kinematic viscosity, and density, were analysed after magnetizing them. The magnetization processes were conducted in two conditions of liquids. At the first stage, the authors magnetized the liquids in stationary conditions; at the second stage, they magnetized the flowing liquids and analysed the difference among all the obtained results. This article shows the results of the comparisons and analyses the magnetic field influence on different types of fluids. Moreover, the paper investigates the dependence of magnetic field strength on the influence of magnetic field on liquids. It was found that the examined three parameters of liquids were changed after magnetic field treatment. The finding of this research offered a simple approach to improve the lubricating and cooling process in machining details in manufacturing.
\end{abstract}

ABSTRAK: Dalam makalah ini, pengaruh medan magnet pada cecair pendingin pelincir, yang digunakan dalam proses pemotongan dalam pembuatan, telah dikaji. Kami memilih tiga cecair penyejuk pelincir berbeza yang biasa digunakan di kilang pembuatan tempatan untuk menjalankan eksperimen. Tiga sifat utama pelincir ini seperti takat didih, kelikatan kinematik, dan ketumpatan dianalisis setelah memagnetkannya. Proses pembesaran dilakukan dalam dua keadaan cecair. Pada peringkat pertama, kami memagnetkan cecair dalam keadaan pegun dan membandingkan hasilnya; pada peringkat kedua, kami memagnetkan cecair semasa mengalir dan menganalisis perbezaan antara hasil yang diperoleh. Artikel menunjukkan hasil perbandingan ini dan menganalisis pengaruh medan magnet pada pelbagai jenis cecair. Lebih-lebih lagi, makalah ini meneliti pergantungan kekuatan medan magnet terhadap pengaruh medan magnet pada cecair. Didapati bahawa tiga parameter cecair yang diperiksa diubah setelah rawatan medan magnet. Penemuan penyelidikan ini menawarkan pendekatan mudah untuk meningkatkan proses pelinciran dan penyejukan dalam perincian mesin dalam pembuatan.

KEYWORDS: boiling point; cutting, liquid; magnetic field; manufacture 


\section{INTRODUCTION}

There are many scientific works about the effect of magnetic field on the physical and chemical properties of water. When liquids are exposed to magnetic field effects, they become magnetized liquids. Nikolskiy et al. analytically and experimentally investigated the influence of magnetic and electric fields with tension gradient in the direction of the movement of the contacting gas-liquid phases [1]. Rashid at al. presented an investigation of water evaporation through a magnetic field of $0.5 \mathrm{~T}$, which was located at different locations of tested water height (water-air interface, water mid-height, and bottom) [2]. Amiri and Dadkhah investigated whether or not a physical water treatment reduces the surface tension of water, as reported in some scientific literature [3]. Tritigin et al. studied the influence on the microflora of water-oiled lubricating cooling liquid of a weak electromagnetic pulse field [4]. Ageev noted that one of the hypotheses explaining the effect of a weak magnetic field on biological objects is that water properties were changed by magnetic field [5]. Hassan and Rahmon's study is a step towards gaining a better understanding of the effect of magnetism on water properties and on the biology of culture organisms, such as the brine shrimp, Artemia salina. Their study evaluated the effects of magnetic field exposure on water properties, which in turn affected the hatchability of A. salina [6]. Baresel et al. have taken the concept of water treatment by functionalized magnetic particles one step forward by integrating the technology into a complete proof of concept, which included the preparation of surface-modified beads, their use as highly selective adsorbents for heavy metals ions (zinc, nickel), and their performance in terms of magnetic separation [7]. Mardonov et al. studied the effect of magnetic field on the dynamic viscosity coefficient of flowing water. They found that the dynamic viscosity coefficient of water changed after magnetization. They magnetized flowing water using different magnetic field strengths. After magnetization, they measured the coefficient and found that dynamic viscosity of water was decreased [8].

The effect of magnetic field on liquids is still a controversial issue, and there is a lack of research in this field. Almost all of the research about magnetic field effect on liquids were conducted on water and the majority of that research was effectively used in the agriculture field. The authors of this paper suggest that use of magnetic field treatment in the manufacturing process would have a great advantage.

Although many scientific works about the influence of magnetic field on some parameters of water have been reported from many studies, no scientific works analysed the effect of magnetic field on lubricating cooling liquids, which are used in cutting processes. Kinematic viscosity, boiling point, and density are effectively the most important parameters of lubricating cooling liquids used in cutting processes. Analysing the influence of magnetic fields on the properties of lubricants would help to increase the efficiency of machining and increase the wear resistance of the cutting tool. The purpose of this research work is to study the effect of magnetic field on these three properties of lubricating cooling liquids such as boiling point (heating from room temperature until the liquids boil), kinematic viscosity, and density. The experiment suggests that some parameters of liquids, such as boiling point, kinematic viscosity, and density were changed by the magnetic field. It is essential to point out that in this research, three different liquids were studied, including water, and the results were applicable for other types of liquids. It has been proven, here, that magnetic field treatment decreases the boiling point of any liquid with respect to the magnetic field strength. In addition, the effect of magnetic field on kinematic viscosity and density of liquids were investigated in this study. Moreover, the influence of the magnetic field strength on magnetization effect was studied. 


\section{METHODS AND MATERIALS}

\subsection{Magnetization}

The first liquid (liquid-1) was tap water and it was from a local water supply company ("Suvsoz", Uzbekistan), the second and the third liquids (liquid-2 and liquid-3) were taken from a local manufacturing factory (Meridian-A). These three liquids were used as lubricating cooling liquids in the "Meridian- $\mathrm{A}$ " manufacturing factory. The second liquid, liquid-2, was a compound of water and $\mathrm{K}_{2} \mathrm{Cr}_{2} \mathrm{O}_{7}$ powder with $0.2 \%$ concentration. More accurately, $\mathrm{m}=50$ grams $\mathrm{K}_{2} \mathrm{Cr}_{2} \mathrm{O}_{7}$ powder was dissolved in $\mathrm{m}_{0}=25 \mathrm{~kg}$ of water. Lubricating cooling liquid with that concentration is used in cutting details made from mild steel. Liquid3 is also a lubricating cooling fluid and it is mainly used for machining details where the material's hardness is higher (hard alloys) than other details. It is a 5\% concentration of special cutting fluid marked BM-76M with water.

The magnetizing equipment UMD-1 was developed for magnetizing liquids, the equipment consisted of 8 magnets, and the size of each magnet was 120x80x16 (length, width, height) with a minimum strength of $40 \mathrm{Mt}$. The details of UMD-1 magnetizing equipment are given in Fig. 1.

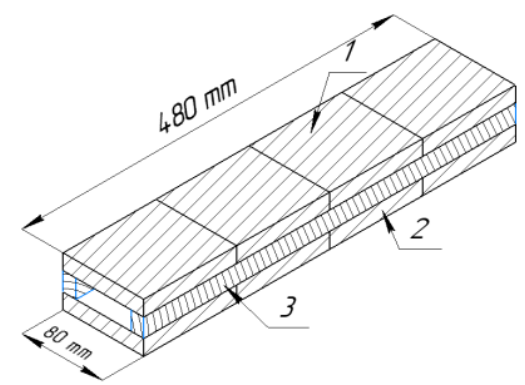

Fig. 1: UMD-1 magnetizing equipment.

1 - Magnets on the top, 2 - magnets below, 3 - wooden part for separation.

Four magnets (1) were placed on the other four (2) with a gap between them. They were separated by a non-conductor material (3) between them. Three types of magnetic field strength $(40 \mathrm{mT}, 60 \mathrm{mT}, 80 \mathrm{mT})$ were selected to magnetize the liquids and magnetic field strength was controlled by changing the distance between magnets. More clearly, changing the non-magnetic parts with ones of different height, resulted in various magnetic field strengths. A PVC pipe was placed between the magnets, and its diameter was $10 \mathrm{~mm}$. Four hundred eighty $\mathrm{mm}$ of the polyvinyl chloride (PVC) pipe passed through UMD-1 magnetizing equipment and this was the length of the magnetic field. When a liquid flowed through the PVC pipe, it turned into a magnetized liquid. All of the samples circulated at a flowing speed of $0.4 \mathrm{~m} / \mathrm{s}$ for $30 \mathrm{~min}$ in UMD-1 magnetizing equipment. The scheme of the magnetizing process is given in Fig. 2.

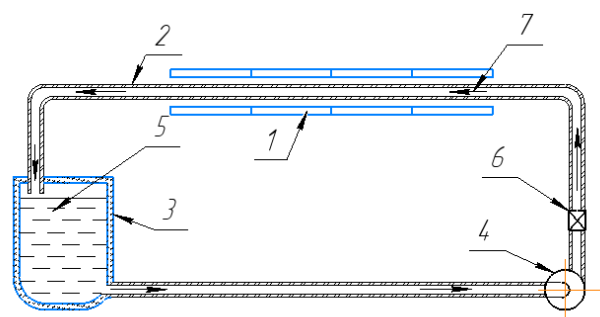

Fig. 2: 1 - UMD-1 magnetizing equipment, 2 - PVC pipe, 3 - container, 4 - pump, 5 - liquid, 6 - tap, 7 - flowing direction of the liquid. 
The magnetic field strength, magnetizing condition, and velocity of liquids were considered as three influential factors that affected the changes caused by the magnetic field $[9,10]$. Therefore, all of the experiments were conducted in the same laboratory conditions and the specification of the laboratory conditions is given in Table 1.

Table 1: Example system technical data

\begin{tabular}{cc}
\hline Item & Value \\
\hline Atmospheric pressure & $770 \mathrm{mmHg}$ \\
Humidity & $80 \%$ \\
Height above sea level & $440 \mathrm{~meter}$ \\
Flowing speed of liquid & $0.4 \mathrm{~m} / \mathrm{s}$ \\
Diameter of the PVC & $10 \mathrm{~mm}$ \\
\hline
\end{tabular}

\subsection{Measurement of the Kinematic Viscosity}

A capillary glass viscometer VPJ-4 (Fig. 3) is one of the commonly used devices to measure the viscosity coefficient of liquids and it was designed to determine the kinematic viscosity of liquids in accordance with GOST 33-66. Its range of measurement is from 0.6 $\mathrm{mm}^{2} / \mathrm{s}$ to $10000 \mathrm{~mm}^{2} / \mathrm{s}$ and it was very easy to measure and is also a popular method for measurement in laboratory conditions. Capillary viscometer VPJ-4 (Fig. 3) is a device in the form of a U-shaped tube, the elbow (1) is soldered with the capillary (5). Measuring viscosity by a viscometer is based on the determination of the time required for a certain volume of liquid to flow out through the capillary.

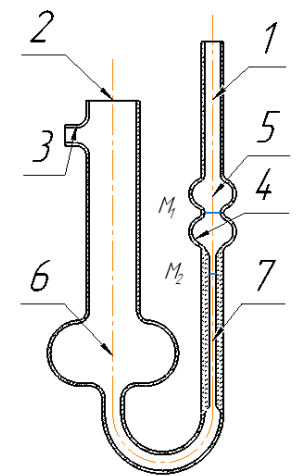

(a)

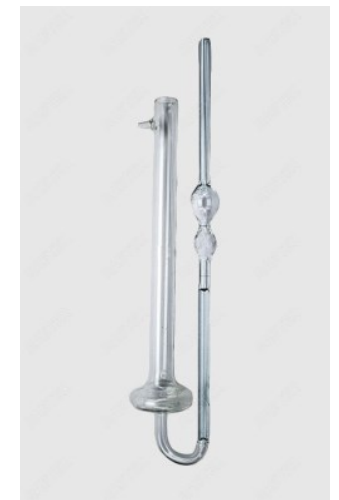

(b)

Fig. 3: VPJ-4 capillary viscometer.

1, 2 - bend of the viscometer; 3 - discharge pipe; 4 - upper reservoir of the viscometer; 5 - capillary; 6 - lower reservoir of the viscometer; $\mathrm{M}_{1}$ and $\mathrm{M}_{2}$ - labels, limiting the measured volume of the lower reservoir viscometer.

To determine the flow time to the discharge pipe (3), a rubber tube connected to a rubber bulb was inserted. Then, holding the bend (2), the viscometer was turned over and the bend (1) was immersed in a reservoir with liquid. The liquid was sucked in (with a pear) to the $\mathrm{M}_{1}$ mark, without letting air bubbles form in the liquid. At the moment when the liquid reached the $\mathrm{M}_{2}$ mark, the device was removed from the vessel and immediately turned over to its original position. Excess fluid was removed from the bend (1), the rubber tube was removed from the bend (2), and it was put on the bend (1). Then, the viscometer was placed in the thermostat so that the expansion (4) was lower than the liquid level in the thermostat. It was kept in a thermostat for more than 30 minutes at a given temperature and then the 
liquid was sucked into the bend to the level of one-third of the expansion (4). The rubber tube was disconnected and the time for the meniscus level to drop from the $\mathrm{M}_{1}$ mark to the $\mathrm{M}_{2}$ mark was measured with a stopwatch.

The diameter of the capillary was $3.55 \mathrm{~mm}$. The kinematic viscosity of the liquid was determined using the following Eq. (1) [GOST 33-66],

$$
V=\frac{g}{9.807} \cdot T \cdot K
$$

where,

$K$ - Constant of the viscometer (9.224 $\mathrm{mm}^{2} / \mathrm{s}^{2}$ according to GOST 33-66)

$V-$ Kinematic viscosity of liquid $\left[\mathrm{mm}^{2} / \mathrm{s}\right]$

$T$ - Liquid flow time in seconds

$g-$ Acceleration of gravity $\left[\mathrm{m} / \mathrm{s}^{2}\right]$

\subsection{Measurement of the Density}

Density is one of the main physical quantities that characterizes the properties of a substance. When exercising control over technological processes and product quality, measuring the density of substances plays an essential role. It is known that to determine the density of a solid or liquid, it is sufficient to define the ratio of body weight to its volume. On the other hand, the ratio of the densities of a solid and a liquid determines, for example, the condition for the floating of a solid in a liquid, and the values of their density are the magnitude of the pushing forces from the liquid and the weight of the body inside the liquid. This relationship opens the ability to measure density through the interaction of a liquid and a solid immersed in that liquid. In our experiment, we used the densimeter with second class of accuracy according to GOST 1300-57 and its measurement range was from 1.000 to 1.800 (Fig. 4).

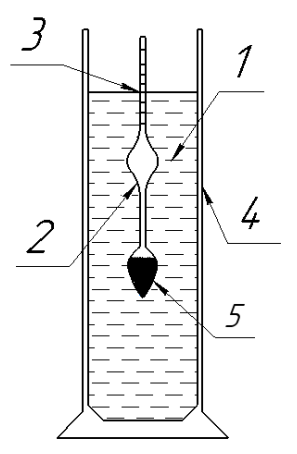

(a)

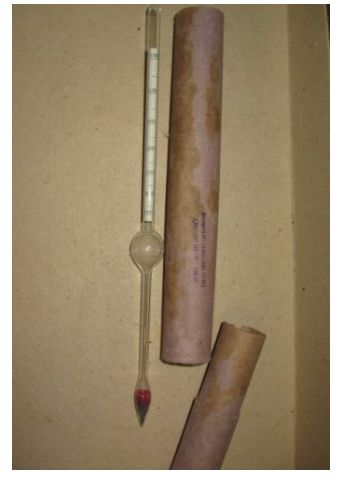

(b)

Fig. 4: 1 - Liquid; 2 - Densimeter; 3 - Density measuring scale of the densimeter; 4 tanker, 5 - Ballast.

Densimeters and hydrometers are commonly used to measure the density of different types liquids. The densimeter is a glass float of constant mass and volume, the expanded (lower) part of which is filled with ballast - clean and dry metal shot, filled with a layer of resin with a melting point of at least $80{ }^{\circ} \mathrm{C}$. Thanks to the ballast (5), the densimeter is in a vertical position during measurements. In the upper thinned part of the float, there is a scale graduated in units of density. The use of a densimeter to determine the relative density of a liquid is based on Archimedes' law, therefore, the upper divisions of the scale correspond to 
the lowest density, and the lower divisions correspond to the highest density. The readings are counted along the lower meniscus of the fluid. In the manufacturing and canning industry, sets of standard general-purpose densimeters of at least $2^{\text {nd }}$ class of accuracy are used, calibrated to measure the relative density at a temperature of $20{ }^{\circ} \mathrm{C}$ with a measurement range from 0.7000 to 1.840 or from 820 to 1840 , respectively.

\subsection{Measurement of the Boiling Point}

The TP300 (Fig. 5) digital thermometer (Xi'an Lonn M\&E Equipment Co., Ltd., China) was used to measure the boiling point of magnetized and non-magnetized liquids under different conditions. The boiling point is determined by the nature of the substance and depends on external pressure. It is a characteristic of bodies located only in solid-state and for high molecular weight compounds. To determine the boiling point of fluids, we took a container and filled it with liquid $(100 \mathrm{ml})$, and started to heat. While heating we put a TP300 digital thermometer into the liquid and marked the boiling point of the liquid.

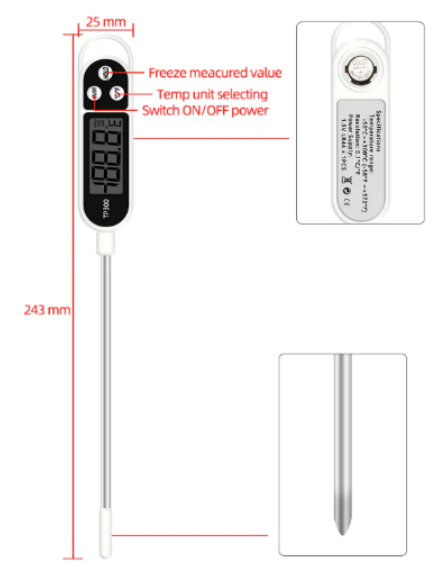

Fig. 5: TP300 digital thermometer (measurement range is from $-50{ }^{\circ} \mathrm{C}$ to $+300{ }^{\circ} \mathrm{C}$ ).

\section{RESULTS AND DISCUSSION}

\subsection{Effect of Magnetic Field on the Boiling Point of Lubricating Cooling Liquids}

The digital thermometer recorded the boiling point of the three different liquids. As stated above, three different liquids were analysed under the influence of magnetic field with three different magnetic field strengths $(40 \mathrm{mT}, 60 \mathrm{mT}$, and $80 \mathrm{mT})$. To compare the results, at first, the boiling point of liquids without magnetic field effect was measured under laboratory conditions. Second, the magnetic field was affected, with a MFS of $80 \mathrm{mT}$, to liquids in a stationary condition (not flowing) and the results were compared. The boiling point results were consistent with reports in the literature that the boiling point of water increases after magnetic field treatment [11]. Figure 6 shows the difference between the obtained results.

It is noticeable from Fig. 6 that liquids under the effect of magnetic field in peace (still) condition, have lower boiling point than their natural boiling point. Every liquid's natural boiling points differed from each other, but when they were affected by the magnetic field, there was difference between boiling points of magnetized liquids in peace condition and non-magnetized liquids. Then the effect of the magnetic field with different MFS on flowing liquids was analysed. After 30 minutes of magnetic treatment under each magnetic field strength in the same laboratory condition, as specified in Table 1, the following results, given in Fig. 7, were obtained. 


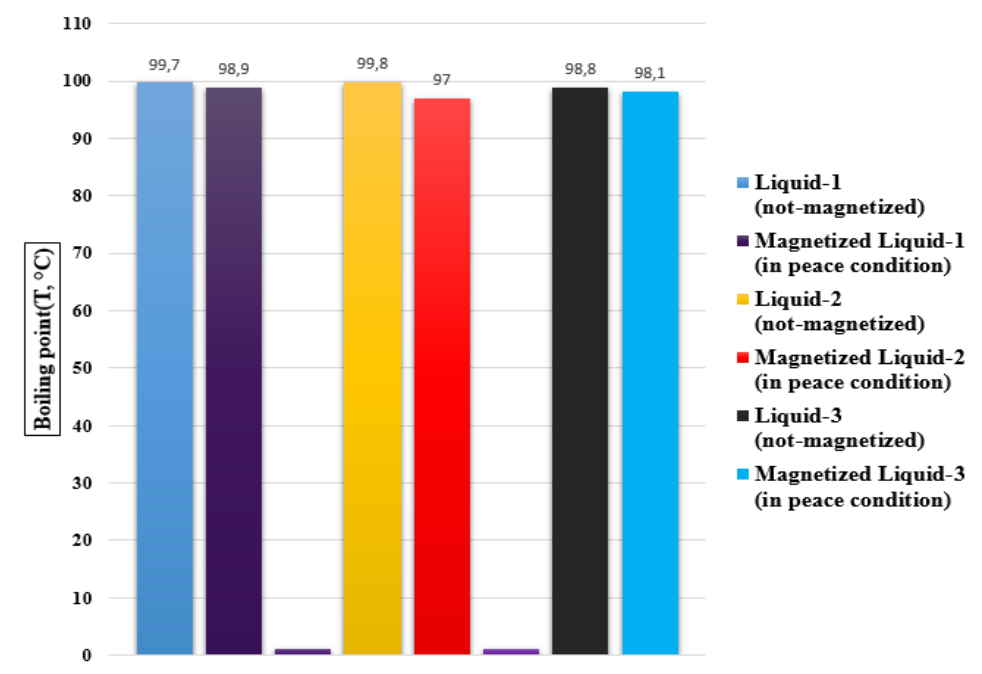

Fig. 6: The boiling point of not-magnetized and magnetized (in peace condition) liquids.

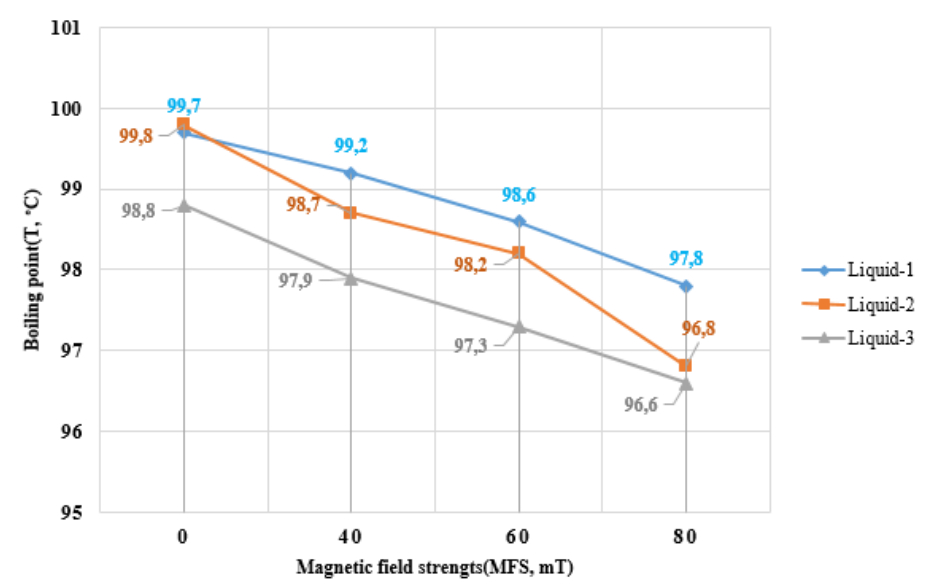

Fig. 7: The boiling point of not-magnetized and magnetized (in the flowing condition) liquids.

The boiling point is one of the main physical parameters of fluids and its value might be changed under the effect of the magnetic field. The boiling point of liquids depends on the condition and other parameters of liquids such as atmosphere and properties of fluids. As can be seen in Fig. 7, the boiling point of magnetized liquids decreases as magnetic field strength increases. The difference between boiling point of not magnetized and magnetized fluids (in the flowing condition) under the $80 \mathrm{mT}$ of magnetic field strength were $1.9^{\circ} \mathrm{C}$ for liquid-1, $3{ }^{\circ} \mathrm{C}$ for liquid-2, and $2.2{ }^{\circ} \mathrm{C}$ for liquid-3 respectively. In addition, it is interesting to note that the higher the magnetic field strength the lower the boiling point of the liquids. The lowest boiling point was determined in $80 \mathrm{mT}$ magnetic field strength. It was found that, if magnetic field strength was increased the effect of magnetic field on liquids was also increased.

\subsection{Effect of Magnetic Field on the Kinematic Viscosity Coefficient of Lubricating Cooling Liquids}

Viscosity coefficient is one of the important properties of lubricating cooling liquids used in the machining process in manufacturing. Analysing the effect of magnetic field on that parameter of liquids will help to increase the efficiency of the manufacturing process. 
Under laboratory conditions, the VPJ-4 measuring device was used to record the results. This device commonly used in Uzbekistan.

To analyze the effect of the magnetic field on the viscosity coefficient of liquids, the three different lubricating cooling liquids in stationary condition were magnetized for 30 minutes. Eight permanent magnets with $80 \mathrm{mT}$ magnetic field strength were used to make the magnetizing condition. Then, the viscosity coefficient of unmagnetized and magnetized (in peace condition) liquids (Fig. 8) were compared. It is clear from the data given in Fig. 8, that under the influence of the magnetic field, the kinematic viscosity coefficient of each liquid decreased noticeably. The difference between kinematic viscosity coefficient of unmagnetized and magnetized liquids were $0.323 \mathrm{~mm}^{2} / \mathrm{s}$ for liquid-1, $0.057 \mathrm{~mm}^{2} / \mathrm{s}$ for liquid-2, and $0.156 \mathrm{~mm}^{2} / \mathrm{s}$ for liquid-3.

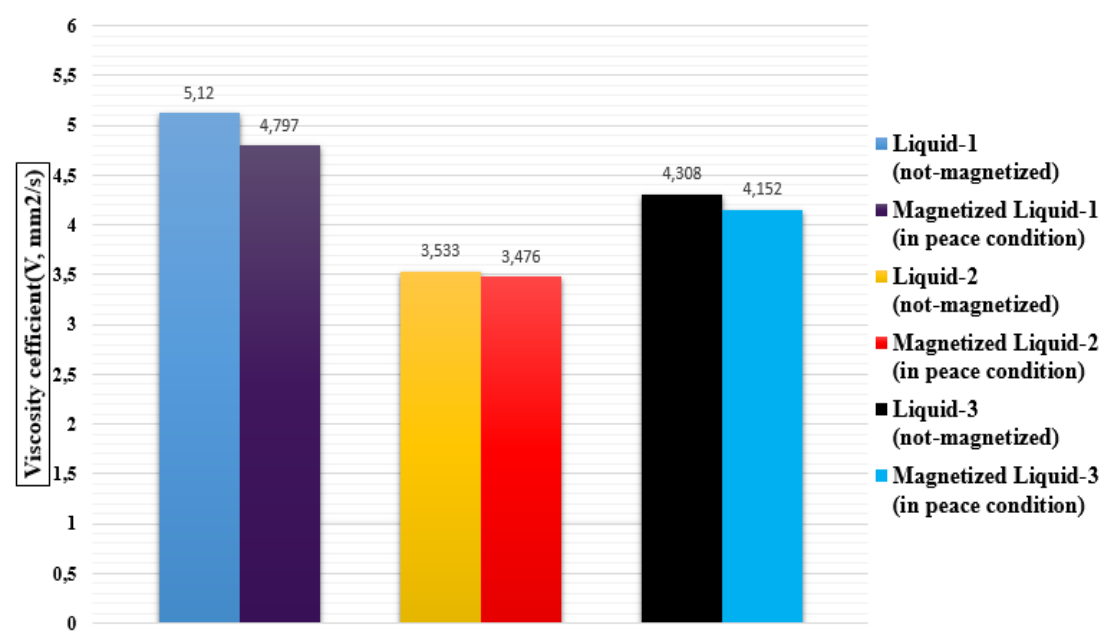

Fig. 8: The kinematic viscosity coefficient of not magnetized and magnetized (in peace condition) liquids.

Following this experiment, the influence of the magnetic field on flowing liquids was assessed. A UMD-1 magnetizing device was used to magnetize the flowing liquids. Lubricating cooling liquids passed through the UMD-1 magnetizing device at $0.4 \mathrm{~m} / \mathrm{s}$. The diameter of the pipe, which was used to pass flowing liquid through the UMD-1, was 10 $\mathrm{mm}$. After 30 minutes of the magnetizing process, the kinematic viscosity of liquids was measured and the results are given in Fig. 9.

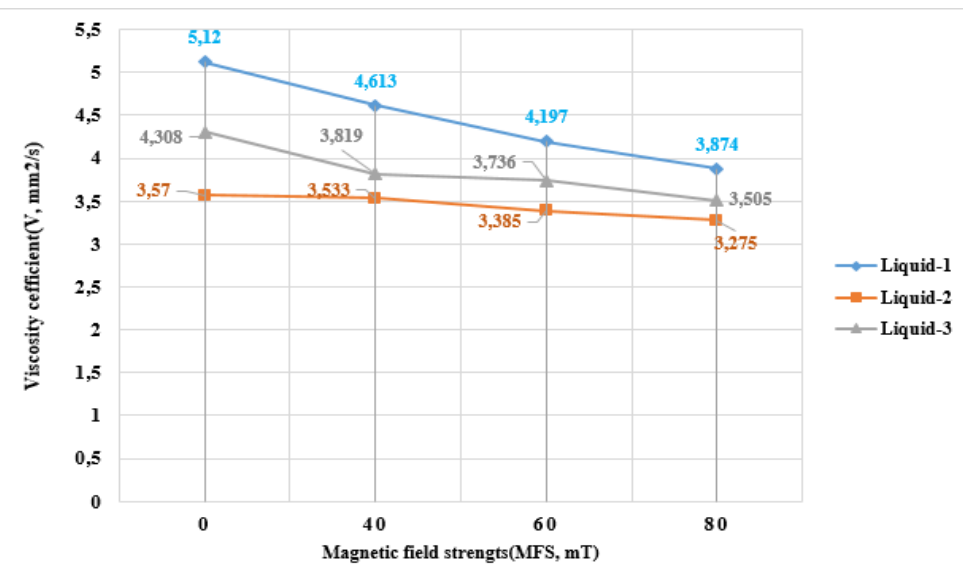

Fig. 9: Viscosity coefficient of not magnetized and magnetized (in flowing condition) liquids in different magnetic field strengths. 
Results given in Fig. 9 show that a magnetic field can cause a decrease in the viscosity coefficient of flowing liquids. Moreover, the viscosity coefficient of flowing liquids depends on the magnetic field strength, because as the strength of the magnetic field increases, the kinematic viscosity of liquids decreases. The lowest viscosity coefficient was determined under the influence of the highest magnetic field strength $(80 \mathrm{mT})$. Comparisons show that the value between the unmagnetized and magnetized liquids, under the highest MFS, were $1.246 \mathrm{~mm}^{2} / \mathrm{s}$ for liquid- $1,0.803 \mathrm{~mm}^{2} / \mathrm{s}$ for liquid-2, and $0.295 \mathrm{~mm}^{2} / \mathrm{s}$ for liquid3.

It was also found that the effect of magnetic field on flowing and not flowing liquids depends on the properties of the liquids. It is clear from the numbers obtained in Figs. 8 and 9 that liquid-1 was affected by the magnetic field more than the other two liquids. Liquid-3 had the least change among the three liquids after magnetization. Because the concentration of liquid-3 has more components than other liquids and its crystals are differentiated from tap water (liquid-1) more than liquid-2. It is investigated that the greater the percent concentration of liquids, the less the magnetization effect on the liquids.

\subsection{Effect of Magnetic Field on the Density of Lubricating Cooling Liquids}

The magnetic field effect on the density of lubricoolants is also important in machining details in the manufacturing process. For the purpose of increasing efficiency in machining details, the effect of magnetic fields on the density of liquids was given greater attention by authors. As above, at first, the difference between the density of unmagnetized and magnetized (in peace condition) liquids was compared. There were also differences among the obtained results (Fig. 10). Figure 10 shows that after magnetizing liquids, their density increased and the differences were $0.002 \mathrm{~g} / \mathrm{cm}^{3}$ for liquid-1, $0.001 \mathrm{~g} / \mathrm{cm}^{3}$ for liquid-2 and $0.002 \mathrm{~g} / \mathrm{cm}^{3}$ for liquid-3.

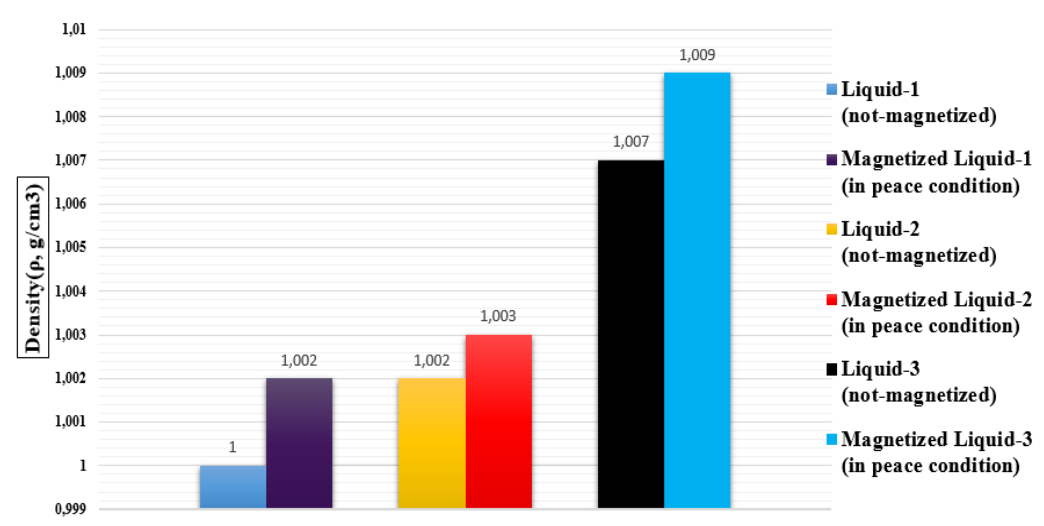

Fig. 10: The density of unmagnetized and magnetized (in peace condition) liquids.

When the flowing liquids were magnetized in different magnetic field strengths, the results changed noticeably with respect to the magnetic field strength. The results, which were taken in the same laboratory conditions, are given in Fig. 11.

Despite the fact that the density of the liquids differed from each other in the same conditions, the density of each liquid was increased after 30 minutes of the magnetization process while they were flowing (Fig. 11). The density of the first sample was $1.000 \mathrm{~g} / \mathrm{cm}^{3}$ before magnetization, but it reached to $1.005 \mathrm{~g} / \mathrm{cm}^{3}$ after magnetizing at $40 \mathrm{mT}$. When the MFS increased to $80 \mathrm{mT}$, the density reached its highest point in the experiment (1.007). Liquid-2 and liquid-3 also increased from $1.002 \mathrm{~g} / \mathrm{cm}^{3}$ to $1.006 \mathrm{~g} / \mathrm{cm}^{3}$ and from $1.009 \mathrm{~g} / \mathrm{cm}^{3}$ 
to $1.011 \mathrm{~g} / \mathrm{cm}^{3}$ respectively. In fact, the highest density was obtained at $80 \mathrm{mT}$ of magnetic field strength.

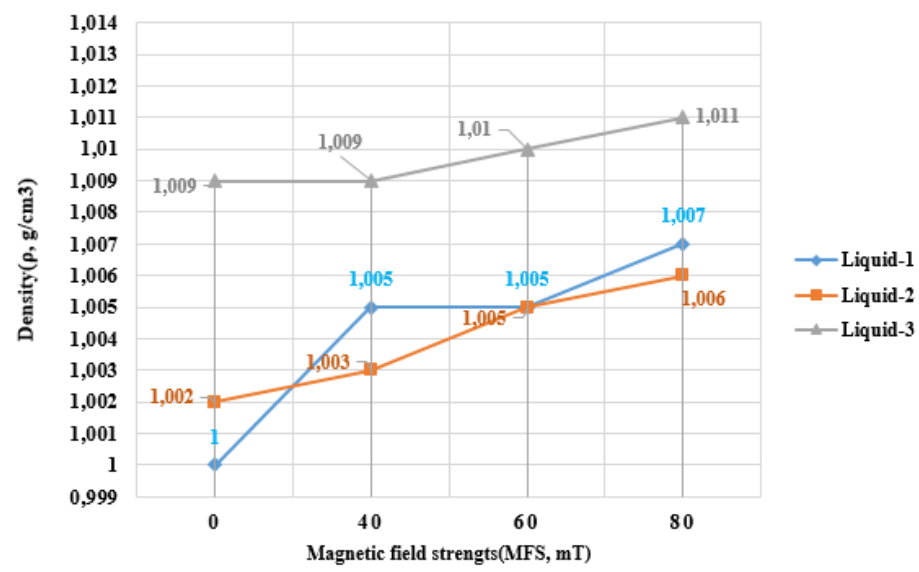

Fig. 11: The density of unmagnetized and magnetized (in flowing condition) liquids in different magnetic field strengths.

A decrease in the viscosity coefficient after magnetic field treatment was found. When magnetic field influences liquids, their crystals are regulated in the magnetic field direction by the magnetic field. This regulation of crystals causes a decrease in the viscosity coefficient after magnetic field treatment. Moreover, the regulation of crystals causes an increase in the density after magnetic field treatment. Also, it has been explored that, the effect of magnetic field on liquids depends on the properties of fluids, or more accurately, in the same laboratory condition and same magnetic field strength, magnetic field influence was different on various liquids. It is worth noting that the influence of a magnetic field on liquid depends on what kind of chemical elements are dissolved in the liquid. Moreover, the maximal change in all of the experiments was obtained at $80 \mathrm{mT}$ of magnetic field strength while the lowest change was reached at $40 \mathrm{mT}$ of magnetic field strength.

Obtained results are very influential to manufacturing processes because the changes in these parameters of liquids have an impact on the wear resistance of the cutting tool used in the machining process. The influence of magnetized lubricating cooling liquids on the wear resistance of cutting tools helps to increase the efficiency in the machining process and saves energy $[8,15,16]$.

However, this issue about magnetic field treatment of liquids remains controversial. Complete understanding of the influence of magnetic fields on fluids has a great impact on agriculture, industry, and other fields [12-14]. Some scientists are working on the issue of magnetic field treatment of water, but there lack of researches on this issue, especially the magnetic field effect on different liquids.

\section{CONCLUSION}

The results obtained in the laboratory experiment showed that there was an increase in the density of liquids when they were affected by the magnetic field. In spite of the fact that the increase was not always noticeable on the density of fluids, it depended on the magnetic field strength. Also, the density of water was more affected by the magnetic field than the other two dissolved liquids which means that the density of dissolved liquids is less likely to be influenced by the magnetic field. However, the influence of the magnetic field on the boiling point of dissolved liquids were about 1.5 times higher than tap water. In addition, 
it was found that kinematic viscosity and boiling point of experimented liquids were decreased after magnetic field treatment. However, after magnetic field treatment of flowing liquid, the kinematic viscosity of liquid- 1 decreased by $24 \%$ while the kinematic viscosity of liquid- 2 and liquid-3 decreased by $8 \%$ and $19 \%$ respectively. The difference between the effect of magnetic field on stationary and flowing liquids was also examined and it was explored that flowing liquids were influenced more than liquids in stationary conditions.

\section{REFERENCES}

[1] Nikolskiy VY. (2017) Primenenie elektromagnitnyx poley dlya intensifikatsii teplomassoobmena $\mathrm{v}$ sovmeщеnnyx gazojidkostnyx protsessax [Application of electromagnetic fields to intensify heat and mass transfer in combined gas-liquid processes]. Vostochno-Yevropeyskiy Jurnal Peredovyx Texnologiy, 3(8): 1729-3774. https://media.neliti.com/media/publications/307213-application-of-electromagnetic-fieldsfo-6a3064eb.pdf

[2] Rashid FL, Hassan NM. (2013) Increasing water evaporation rate by magnetic field. International Science and Investigation Journal, 2: 61-68. http://isijournal.info/journals/index.php/ISIJ/article/view/12

[3] Amiri MC, Dadkhah AA. (2006) On reduction in the surface tension of water due to magnetic treatment. Colloids and Surfaces A: Physicochemical and Engineering Aspects: 278(1-3): 252-55. https://doi.org/10.1016/j.colsurfa.2005.12.046

[4] Tyrtygin VN, Sobgayda NA, Potexa VL, Shayxiev IG, Makarova YA. (2013) Vliyanie elektromagnitnogo impulsnogo polya na mikrofloru smazochno-oxlajdayuщey jidkosti [Influence of the electromagnetic pulse field on the microflora of the cutting fluid]. Vestnik Kazanskogo texnologicheskogo universiteta, 16(3):176-178.

https://cyberleninka.ru/article/n/vliyanie-elektromagnitnogo-impulsnogo-polya-namikrofloru-smazochno-ohlazhdayuschey-zhidkosti/viewer

[5] Ageev IM, Shishkin GG, Yeskin S. (2007) Izuchenie Vliyaniya Nizkochastotnogo Magnitnogo Polya Na Vodu [Study of the Effect of Low Frequency Magnetic Field on Water]. Raditexnika i Electronica, 28: 8-16. https://www.elibrary.ru/item.asp?id=10412034

[6] Hassan SM, Ridzwan AR. (2016) Effects of exposure to magnetic field on water properties and hatchability of Artemia salina. ARPN Journal of Earth Sciences, 11(11): 416-23.

[7] Christian B. (2019) Functionalized magnetic particles for water treatment. Heliyon, 5(8): 17. https://doi.org/10.1016/j.heliyon.2019.e02325

[8] Umarov EO, Mardonov UT, Shoazimova UK. (2020) Influence of the magnetic field on the viscosity coefficient of lubricoolant that is used in the cutting proces. International Journal of Mechatronics and Applied Mechanics, 8(2): 144-149.

https://www.doi.org/10.17683/ijomam/issue8.50

[9] Liu B, Gao B, Xu X. (2011) The combined use of magnetic field and iron-based complex in advanced treatment of pulp and paper wastewater. Chem Eng J, 178(1): 232-238. https://doi.org/10.1016/j.cej.2 011.10.058

[10] Manyà JJ, Jr MJA, Kinoshita CK, Stephen MM. (2011). Specific heat capacity of pure water at 4.0 MPa between 298.15 and 465.65 K. Ind Eng Chem Res, 50(10): 6470-6484. https://doi.org/10.1021/ie102462g

[11] Youkai Wang, Huinan Wei, Zhuangwen Li. (2018) Effect of magnetic field on the physical properties of water. Results in Physics, 8: 262-267. https://doi.org/10.1016/j.rinp.2017.12.022

[12] Wang XY, Zhang B, Gong Z, Gao K, Ou Y, Zhang J. (2013) The effect of a static magnetic field on the hydrogen bonding in water using frictional experiments. J Mol Struct, 1052(11): 102-104. https://doi.org/10.1016/j.molstruc.2013.08.021

[13] Cai R, Yang H, He J, Zhu W. (2009) The effects of magnetic fields on water molecular hydrogen bonds. J Mol Struct, 938(1-3): 9-15. https://doi.org/10.1016/j.molstruc.2009.08.037

[14] Toledo EJL, Ramalho TC, Magriotis ZM. (2008) Influence of magnetic field on physicalchemical properties of the liquid water: insights from experimental and theoretical models. J Mol Struct, 888(1-3): 409-415. https://doi.org/10.1016/j.molstruc.2008.01.010 
[15] Umarov EO, Mardonov UT. (2020) Analysing the effect of magnetic field on Lubricoolant in machining process. International Journal of Applied Research, 6(5): 347-352. https://www.allresearchjournal.com/archives/?year $=2020 \&$ vol=6\&issue $=5 \&$ part $=$ F \&Article $\mathrm{Id}=6723$

[16] Turakhodjaev N, Tashbulatov Sh, Zokirov R, Tursunbaev S, Baydullaev A. (2020) Studying the scientific and technological bases for the processing of dumping copper and aluminum slags. Journal of Critical Reviews, 7(11): 441-444. http://dx.doi.org/10.31838/jcr.07.11.79 